chromatographic determination. J. Chromatogr. A. 2007. Vol. 15, 1153, № 1-2. P. 54-73.

4. Fenichel P., Chevalier N., Brucker-Davis F. Bisphenol A: an endocrine and metabolic disruptor. Ann. Endocrinol. 2013. Vol. 74. № 3. P. 211-220.

5. Rochester J.R. Bisphenol A and human health: a review of the literature. Reprod. Toxicol. 2013. Vol. 42. P. 132-155.

6. De Coster S., van Larebeke N. Endocrine-disrupting chemicals: associated disorders and mechanisms of action. J. Environ. Public. Health. 2012. Vol. 2012. P. 696-713.

7. Council Directive 2010/63/EU of 22 September 2010 on the protection of animals used for scientific purposes. Official Journal of the European Communities. 2010. L. 276. P. 33-79.

8. McEwen B.S., Akama K.T., Spencer-Segal J.L., Arpino G. Estrogen effects on the brain: actions beyond the hypothalamus via novel mechanisms. Behav Neurosci. 2012. Vol. 126. № 1. P. 4-16.

DOI https://doi.org/10.30525/978-9934-26-111-4-29

\title{
ТРАНСМІСІЙНА ЕЛЕКТРОННА МІКРОСКОПІЯ В МЕДИЦИНІ ТА ЇЇ ПЕРСПЕКТИВИ
}

\author{
Харчук М. С. \\ кандидат біологічних наук,
} науковий співробітник лабораторії біологічних полімерних сполук,

Інститут мікробіології і вірусології імені Д. К. Заболотного

Начіональної академії наук Украӥни, асистент кафедри біології

Національний медичний університет імені О. О. Богомольия

\section{Гурняк О. М.}

кандидат біологічних наук, старший викладач кафедри біології

Національний медичний університет імені О. О. Богомольия м. Київ, Украӥна

Мікроскопічні методи $\epsilon$ методологічним підгрунтям наукових досліджень в галузях біології та прикладної медицини. Світлова мікроскопія (CM) у медико-біологічних дослідженнях у порівнянні 
3 іншими видами мікроскопії є частим у застосуванні методом, що пов'язано $з$ його відносною простотою. Однак, СМ має суттєві обмеження, які зумовлені в першу чергу роздільною здатністю, яка не перевищує 200 нм. СМ дозволяє аналізувати клітинні структури, але для досліджень на субклітинному рівні їі можливостей недостатньо. Технічні здатності трансмісійної електронної мікроскопії (ТЕМ) дають ширші можливості для дослідження біологічних об'єктів. ТЕМ за деяким принципом роботи певною мірою нагадує СМ. Проте, головною відмінністю ТЕМ $є$ використання іншого типу освітлення зразків: у СМ - це видиме світло, а у ТЕМ - промінь електронів. Враховуючи корпускулярно-хвильову природу згаданого потоку електронів, вдається досягати значно більшої роздільної здатності мікроскопу, яка може становити кілька ангстремів. ТЕМ дозволяє отримати збільшення об'єктів вивчення від кількох тисяч до мільйона разів і навіть більше, тоді як СМ обмежена збільшенням у 1-1,5 тисяч разів. Така перевага TEM над СМ значно розширює діапазони біологічних досліджень i прикладної медицини й стає вкрай актуальною для розвитку нанотехнологій. Саме завдяки ТЕМ вдалося візуалізувати особливості будови вірусів та ультраструктуру клітин різних організмів. Завдяки TEM можна вивчати морфологічні зміни на клітинному та субклітинному рівнях організації живого, що відбуваються за розвитку патологічних процесів в організмі, репродукції вірусних часток в ньому тощо. Однак, можливості використання ТЕМ в діагностиці значно обмежені оскільки: 1) трансмісійні електроні мікроскопи є чутливими приладами, а їх експлуатація потребує певних особливих приміщень $\mathrm{i}$ локацій; 2) обслуговування трансмісійного електронного мікроскопа забезпечують висококваліфіковані спеціалісти; 3) підготовка зразків для дослідження найчастіше $є$ багатоетапною та тривалою. Це обмежує можливість застосовувати ТЕМ для потокових медико-біологічних досліджень за вимог швидкого і достовірного діагностування. Однак, частково, як додатковий діагностичний метод, ТЕМ може знаходити використання у великих дослідницьких центрах. На практиці вже проводяться діагностичні процедури з використанням ТЕМ, спрямовані на уточнення висновків, зроблених за попередньо отриманих гістологічних, фізіологічних, імунологічних і біохімічних даних. ТЕМ разом зі світловою і імунофлуоресцентною мікроскопією $є$ важливим методом в діагностичних дослідженнях біоптатів нирок у пацієнтів 3 відповідними захворюваннями [1-5]. Окрім того, ТЕМ є одним 3 інструментів для досліджень вірусів та мікроорганізмів, розширює можливості діагностики хвороб спричинюваних ними [6]. Так, ТЕМ 
використовувалась для діагностування присутності вірусу в трансплантованій нирці [7]. За допомогою цього методу було виявлено збудника Q-лихоманки - бактерію Coxiella burnetti - на нативних i штучних клапанах серця [8]. Також даний метод, незважаючи на обмеженість застосування, залишається важливим для діагностування онкологічних захворювань в людини $[9,10]$.

Таким чином, ТЕМ $є$ достатньо важливим методом у діагностуванні певних патологій, дослідженнях біоптатів тканин. Розвиток та вдосконалення передових технологій мікроскопії відкривають перспективи застосування досягнень у цій сфері в різних галузях біології та прикладної медицини. Розробляються експрес-методи, які дозволяють підготувати зразки для ТЕМ за декілька годин [11], що робить згаданий підхід більш доступним у використанні.

\section{Література:}

1. Howell D.N., Herrera G. Electron microscopy in renal pathology: overall applications and guidelines for tissue, collection, preparation, and stains. Ultrastructural Pathology. 2021. V. 45(1). P. 1-18.

2. Haas M. A reevaluation of routine electron microscopy in the examination of native renal biopsies. Journal of the American Society of Nephrology. 1997. 8(1). P. 70-76.

3. Rivera A., Magliato S., Meleg-Smith S. Value of electron microscopy in the diagnosis of childhood nephrotic syndrome. Ultrastructural Pathology. 2001. 25(4). P. 313-320.

4. Pearson J.M., McWilliam L.J., Coyne J.D., Curry A. Value of electron microscopy in diagnosis of renal disease. Journal of Clinical Pathology. 1994. V.47(2). P. 126-128.

5. Collan Y., Hirsimäki P., Aho H.,Wuorela M., Sundström J., Tertti R., Metsärinne K. Value of electron microscopy in kidney biopsy diagnosis. Ultrastructural Pathology. 2005. V. 29(6). P. 461-468.

6. Curry A, Appleton H., Dowsett B. Application of transmission electron microscopy to the clinical study of viral and bacterial infections: present and future. Micron. 2006. V. 37(2). P. 91-106.

7. Herrera GA, Veeramachaneni R, Turbat-Herrera EA. Electron microscopy in the diagnosis of BK-polyoma virus infection in the transplanted kidney. Ultrastructural Pathology. 2005. V. 29(6). P. 469-74.

8. Isalska B.J., Curry A., Stanbridge T.N., Tweddle D., Caul E.O. Electron microscopy and serological features of a patient with $\mathrm{Q}$ fever prosthetic valve endocarditis. Journal of Clinical Pathology. 1996. V. 49(8). P. 679-681. 
9. Ordóñez N.G., Mackay B. Electron microscopy in tumor diagnosis: indications for its use in the immunohistochemical era. Human Pathology. 1998. V. 29(12): P. 1403-1411.

10. Eydenf B. Electron microscopy in the diagnosis of tumours. Current Diagnostic Pathology. 2002. V. 8(4). P. 216-224.

11. Schroeder J.A., Gelderblom H.R., Hauroeder B., Schmetz C., Milios J., Hofstaedtera F. Microwave-assisted tissue processing for sameday EM-diagnosis of potential bioterrorism and clinical samples. Micron. 2006. V. 37(6). P. 577-590.

DOI https://doi.org/10.30525/978-9934-26-111-4-30

\title{
ГЕНЕТИЧНА ДИФЕРЕНЦАЦІЯ МІДІЙ РОДУ MYTILUS ПІВНІЧНО-ЗАХІДНОЇ ЧАСТИНИ ЧОРНОГО МОРЯ
}

\author{
Чубик I. Ю. \\ аспірантка \\ Одеський національний університет імені I. I. Мечникова \\ Чеботар C. B. \\ доктор біологічних наук, професор, \\ завідувач кафедри генетики та молекулярної біології \\ Одеський національний університет імені I. I. Мечникова \\ м. Одеса, Украӥна
}

Мідії роду Mytilus є одними з найпоширеніших морських молюсків, що зустрічаються в прибережніх екосистемах обох півкуль [4]. На основі популяційно-генетичних методів дослідження було встановлено, що мідії Північної півкулі складаються з «видового комплексу Mytilus», до якого відносять три види: Mytilus galloprovincialis Lamarck, 1819, Mytilus edulis Linnaeus, 1758; Mytilus trossulus Gould, 1850 [7]. Особини цих видів, у зв'язку з високою генетичною подібністю, здатні схрещуватися між собою утворюючи гібридні зони в різних районах Світового океану [1].

Можливість точної ідентифікації видів та гібридів у «видовому комплексі Mytilus» має важливе значення для селективного управління запасами мідій та досліджень біорізноманіття [9].

Мідій Чорного моря за морфологічними характеристиками зазвичай відносять до виду M. galloprovincialis. Проте, серед особин мідій 128 